\title{
ПЕРСПЕКТИВЫ РАЗРАБОТКИ СТАНДАРТНЫХ ОБРАЗЦОВ НИТРОПРОИЗВОДНЫХ ФУРАНА
}

\author{
К.В. Ламанова', И.О. Гречишкин', Н.В. Словеснова ${ }^{1,2,3}$, Е.Б. Сысуев', \\ А.Ю. Петров ${ }^{1}$
}

${ }^{1}$ Кафедра фармации и химии, Уральский государственный медицинский университет, 620028, Российская Федерация, Екатеринбург, ул. Репина, 3.

2Органической и биомолекулярной химии,

Уральский федеральный университет имени первого Президента России Б.Н. Ельцина,

620002, Российская Федерация, Екатеринбург, ул. Мира, 19.

ЗЛаборатория координационных соединений, Институт органического синтеза

им. И.Я. Постовского Уральского отделения Российской академии наук,

62013, Российская Федерация, Екатеринбург, ул. Софьи Ковалевской, дом 22/20.

DOI:10.19163/MedChemRussia2021-2021-361_E-mail: lamanovaksenia92@gmail.com

Одной из проблем стандартизации лекарственных субстанций и готовых форм является необходимость наличия доступного стандарта. Высокая стоимость стандартов USP и EP заставляет задуматься о разработке стандартов на территории РФ [1].

Рассмотрены свойства двух нитропроизводных фурана: нитрофурана и фуразолидона. Данные вещества представлены в виде образцов ЕР и USP соответственно.

В качестве технологии получения использовали очистку некондиционной субстанции методами перекристаллизации в двух разных растворителях: диметилформамид и изопропиловый спирт. Полученные образцы были охарактеризованы методами ядерно-магнитного резонанса, инфракрасной спектроскопии, элементного анализа. Также для обна-ружения возможных примесей использовали метод дериватографии и высокоэффективную жидкостную хроматографию. Дополнительно определили рКа данных веществ.

\begin{tabular}{|l|c|c|c|c|}
\hline \multirow{2}{*}{ Элементный анализ } & \multicolumn{5}{|c|}{ Отклонения от расчетных значений, \% } \\
\cline { 2 - 5 } & $\mathbf{C}$ & $\mathbf{H}$ & $\mathbf{N}$ & $\mathbf{0}$ \\
\hline Нитрофуран & 0,068 & 0,015 & 0,388 \\
\hline Перекристаллизация ИПС & $-0,470$ & $\mathbf{0 , 1 3 5}$ & $-8,875$ & $\mathbf{3 , 5 3 5}$ \\
\hline Перекристаллизация ДМФА & $\mathbf{5 , 2 0 5}$ & \multicolumn{5}{|l}{} \\
\hline Фуразолидон & \multicolumn{5}{|l|}{} \\
\hline Перекристаллизация ИПС & $-0,155$ & 0,09 & $-0,205$ & 0,270 \\
\hline
\end{tabular}

В результате исследований выявлено преимущество использования изопропилового спирта в качестве растворителя для перекристаллизации.

\section{Литература}

[1] Петров, А., Сысуев, Е., \& Новикова, Н. Роль технического регулирования и стандартизации в эпоху цифровой экономики. - Екатеринбург, 2020, 21-32. 